\title{
SOBRE PESSOAS E VARIÁVEIS: ETNOGRAFIA DE UMA CRENÇA POLÍTICA*
}

Antonádia Borges

\section{Introdução}

No Distrito Federal encontramos com recorrência, nas apreciações de senso comum a respeito da vida nas cidades que circundam Brasília, uma série de termos que pontuam parte significativa dos estudos sociológicos sobre fenômenos políticos e/ou eleitorais. Não raro, a vida de milhares de pessoas é considerada apolítica, porque marcada pelo clientelismo. Sabemos bem que, ao menos nos textos considerados clássicos, termos como clientelismo, populismo ou coronelismo eram tratados com extremo rigor, sendo invariavelmente referidos a fenômenos específicos, para os quais tais categorias encerravam um valor heurístico preciso (p.ex., Queiroz 1969; Leal 1949). A transposição ordinária desses termos para todo e qualquer contexto indica não apenas a imprecisão teórica daqueles que assim procedem, como descortina seu preconceito. Preconceito moral (moralista e moralizante) que não se desvincula do preconceito sociológico característico desse tipo de apreciação.

Incomodada com essa retórica que tropeça nas pedras pretensamente relativistas espalhadas pelo caminho, procurei compreender como certos fatos sociais totais, por assim dizer - como o Estado, o governo, a política, as eleições - , eram vividos por pessoas que moravam na cidade do Recanto das Emas. Neste artigo, proponho um confronto entre o conhecimento produzido etnograficamente e esse tipo de formulação calcada em antagonismos morais ao analisar as implicações dos sistemas cadastrais desenvolvidos pelo governo local para hierarquizar a população em uma escala de merecedores de um lote. As pessoas que se cadastram se envolvem com os funcionários do governo de forma dissonante: não se trata de uma relação exclusivamente burocrática ou personalista. De seus encontros resultam sobretudo documentos, isto é, registros gráficos, provas materiais que tornam palpáveis e presentes as alterações na vida de ambos. Os papéis que cada 
um traz consigo, de um lado e outro do guichê, remontam as mudanças sem fim por que todos passaram: funcionários, governos e população.

A preocupação com o lote perpassa a vida local em todas as direções, figurando tanto em conversas corriqueiras como nos programas de governo e, para além dos sempre apontados usos eleitoreiros da política habitacional ou dos acidentes biográficos de uma família particular de migrantes, o trabalho etnográfico conduzido por mim no Recanto das Emas entre os anos de 2000 e 2002 demonstra que a existência desse conjunto de crenças compartilhado encontra sua expressão máxima na categoria "Tempo de Brasília". Apenas nos derradeiros momentos da pesquisa pude compreender que esse conceito diz respeito não somente a uma passagem cronológica dos anos vividos na capital federal, mas à conformação de um hábito singular, notado sobretudo nos procedimentos dos moradores e funcionários do governo no que tange à distribuição de benefícios governamentais.

Para demonstrar tal associação, faz-se necessária uma estrutura narrativa que recupere o processo de conhecimento etnográfico. Por isso, inicialmente, apresentarei uma entrevista em que vemos explicitados os envolvimentos sociais obrigatórios que marcam a vida dos moradores da cidade. Logo em seguida, procuro analisar um conjunto de decretos, promulgados por sucessivos e diferentes governos locais, referente à regulamentação da distribuição de lotes para a chamada população de baixa renda. Essas leis, localizadas no âmbito do que poderíamos nomear como engenharia social, dizem respeito às equações matemáticas utilizadas para se calcular o mérito de alguém que pleiteia um lote junto ao governo. Este último material analisado, de qualidade distinta, documental, é compreendido, todavia, mediante a mesma postura cognitiva etnográfica que torna a entrevista inteligível.

A partir de dois objetos aparentemente distintos (uma conversa e um conjunto de documentos), apresento uma análise do comprometimento coletivo, amplamente espraiado entre os moradores do Recanto das Emas, com um lugar para morar. Esses símbolos que trago à tona só podem ser compreendidos em consonância com os demais entendimentos sobre a vida no Recanto (Borges 2003). Entre a entrevista com Dona Maria e Seu Vitório e as fórmulas, há um elo preciso - a noção de "Tempo de Brasília" — por meio da qual experiências sociais de ordens absolutamente diversas puderam ser sintetizadas durante o período de trabalho de campo nessa cidade.

\section{Dona Maria: você não quer entrevistar a gente?}

Encontrei-as ao final da tarde. No meio da rua empoeirada. As duas mu- 
lheres e eu vínhamos de nosso dia de trabalho. Elas eram diaristas em mansões, mas naquele dia tinham visitado casas no próprio Recanto, onde faziam leituras da Bíblia e conversavam com os mais necessitados. Meu trabalho também consistia em sair pelo Recanto das Emas, batendo de porta em porta. Fazia isso diariamente, sobretudo, porque as pessoas com quem eu morava se mostravam incomodadas e ansiosas quando eu demorava a sair de casa pela manhã, preocupadas com o bom andamento de minha pesquisa. Afinal, eu estava ali fazendo um estudo e por isso temiam que eu perdesse tempo ficando com elas, conversando apenas. Para lhes mostrar que eu também corria atrás, vez por outra partia em busca de uma entrevista. Passados dois anos de contato constante com os moradores da cidade, já ao fim do trabalho, comecei a entrevistar alguns deles. Essas entrevistas, curiosamente, ocorreram apenas depois de eu já ter travado um sem-número de conversas. Naquela tarde não foi diferente. Dona Maria interpelou-me: você não quer entrevistar a gente?

Anteriormente, sem muito comprometimento, eu havia combinado de fazer isso. Dentro do espírito jocoso que costumava pontuar as conversas e os espíritos locais, fui repreendida porque, a exemplo de alguns políticos e pessoas falsas, apenas prometia e não cumpria. Como sempre, tentei argumentar que, para a parte mais importante do meu trabalho de pesquisa, as entrevistas não tinham tanta importância. Inútil insistir, habituados a responder questionários de todo o tipo para agentes do governo, os moradores do Recanto das Emas tinham aprendido a falar a linguagem das entrevistas. Era uma obrigação minha atentar para essa habilidade, e não ignorá-la simplesmente, considerando-a ilegítima.

Forçada a aproveitar o meu tempo segui com Lourdes caminhando até a outra quadra, onde morava Dona Maria e seu marido Vitório. A casa de alvenaria sem acabamento estava com as portas e janelas abertas. Esse tipo de habitação, que não é nem um barraco vulnerável, nem uma casa com muro e portões fechados, nos remete à posição mediana, à fixação relativamente estável daquela família ao Recanto das Emas. Os barracos tendem a ser o primeiro teto de quem chega ao local. Os que continuam vivendo em barracos, mesmo que em lote próprio, em geral, acabam vendendo sua propriedade para morar em um lugar mais distante, mais barato. Já as sólidas casas de alvenaria, cercadas por grades altas, indicam o intento de fixar raízes na nova cidade. Embora não seja uma garantia de permanência, essas habitações refletem um investimento nesse sentido. O casal que nos recebia estava, portanto, flutuando entre esses dois pólos.

Seu Vitório aproveitava que não tinha clientes em sua barbearia para debulhar uns caroços de mamona que colhera nos arredores da cidade. 
O Recanto das Emas, embora abrigue mais de cem mil moradores, é uma região administrativa recente, criada em 1993. Esse imenso assentamento urbano em meio ao cerrado, chamado por seus moradores de cidade, fica às margens do Distrito Federal, na fronteira com o estado de Goiás. No campo aberto que circunda a cidade, ele colhera galhos de mamona e agora retirava dos frutos as sementes que seriam torradas e esmagadas para se fazer óleo. Para quê? Perguntei, mas ninguém soube responder. "Dizem que é bom". Sem dúvida, bom para passar o tempo.

O tempo para os moradores do Recanto das Emas é uma questão de suma importância na classificação de suas vidas e, em especial, de sua relação com o governo local. Perder ou ganhar tempo é um tema de muitas conversas, discussões e apreciações sobre o mundo. No entanto, ganha um tom particular quando o objeto ou experiência à qual o tempo se refere diz respeito a um bem público, a uma relação daqueles com o governo. Ganha-se o tempo perdido em uma fila no posto de saúde, por exemplo, quando se consegue uma consulta. Quando as fichas acabam na hora $\mathrm{H}$, perde-se tempo. Perde-se tempo também se, depois do exame, o médico não descobre nada. Em suma, quando alguma coisa acontece como previsto ou desejado, o tempo foi ganho; quando as expectativas são frustradas, perde-se tempo.

Nessas situações ordinárias do cotidiano vemos referências a um tempo manipulável, que ora se perde ora se ganha, mas que é sobretudo exterior aos sujeitos. Há, no entanto, alastrada pelo Recanto das Emas, uma concepção de tempo distinta dessa primeira: o "Tempo de Brasília".

O "Tempo de Brasília" envolve a todos visceralmente porque, ao transcorrer, se inscreve nos indivíduos, tornando-se parte deles próprios. O "Tempo de Brasília" diz respeito, em grande medida, àquilo que as pessoas são, porque se refere ao que cada uma viveu no Distrito Federal. Por meio das situações em que esse conceito é empregado é possível compreender qual o sentido de uma série ritualizada de atitudes que povoam o dia-a-dia dessas pessoas, de tabus e evitações que têm como objeto referencial o "Tempo de Brasília".

Em todo o Distrito Federal, milhares de indivíduos dedicam-se a recolher provas materiais que demonstrem que viveram na capital federal ao longo de cinco anos ou mais. Eles consagram sua energia a essa tarefa porque por meio desse intervalo mínimo de tempo, os governos convencionaram assegurar-se do mérito de todos aqueles desejosos de se tornarem beneficiários de seus projetos assistenciais. Dos benefícios que o governo do Distrito Federal distribui a quem lhe pede, isto é, a chamada população de baixa renda, aquele considerado de maior valor é o lote. Este bem supremo, que grande parte das pessoas procura de diferentes formas obter, 
só é oferecido àqueles que comprovem seu "Tempo de Brasília". Por essa razão, neste caso, o "Tempo de Brasília" é percebido como um atributo pessoal.

Quem deseja inscrever-se para receber um lote do governo deve, obrigatoriamente, preencher esse requisito básico. A esta exigência, condição sine qua non, se acrescenta ainda uma série de informações a respeito do indivíduo e de sua família. Depois de cadastrado, seu nome passa a figurar em uma lista, em que se vêem hierarquizados todos aqueles que aguardam o benefício do governo. Embora a espera seja o modo legal para se conseguir um lote, há outras formas para a população tentar acelerar o moroso processo burocrático. Um desses recursos é a invasão de terras públicas (Borges 2000), isto é, a ocupação de espaços interditos, públicos ou privados, que visam a remoção seguida de assentamento (embora isto se dê raramente, sendo mais comum a investida militar violenta dos agentes de vigilância do solo sobre os barracos erguidos nessas condições). O outro, é o aumento do "Tempo de Brasília", neste caso, dos pontos necessários à contemplação.

A lista oficial na qual se inscrevem os que aguardam estrutura-se mediante o cálculo das qualidades ou "especificidades sociais" do futuro favorecido. Os lotes e todos os outros benefícios devem ser ofertados àquelas pessoas que obtiverem mais pontos, que encabeçarem a lista. Enquanto espera por esse dia de contemplação, quem sonha com um lote pode ocupar um espaço no barraco de um familiar ou amigo, construir um barraco no lote de um familiar ou amigo, alugar um quarto ou um barraco no lote em que mora também o locador ou alugar uma casa que seja a única sobre um mesmo lote.

Seu Vitório e Dona Maria anteriormente moravam em uma região de chácaras. Nesse local, além de tomar conta do sítio de um conhecido, eles mantinham uma vendinha. Dona Maria e Seu Vitório não estavam em uma invasão, não pagavam aluguel e também não viviam com parentes (casos mais comuns no Recanto das Emas), mas como agregados rurais na região do entorno, ou seja, em um lugarejo que fica no estado de Goiás, mas que faz limite com o Distrito Federal ${ }^{1}$. Por isso, seu caso oferece uma outra modalidade de espera e de conquista do lote, razoavelmente distinta das demais.

Os trechos que agora se seguem se referem ao final de uma longa conversa, entre tantas outras. Depois de muita prosa, chegamos ao que em geral é o ápice, ou ao menos um topos freqüente no Recanto das Emas: a singularidade da vinda de cada um para a cidade.

Antonádia: E como é que vocês conseguiram esse lote aqui?

Seu Vitório: Ela [a esposa] fez a inscrição em Brazlândia.

Antonádia: Como é que foi a inscrição, dona Maria?

Dona Maria: A inscrição foi assim: eu sempre ia a Brazlândia porque nós tí- 
nhamos boteco, e eu tinha que ir lá pra comprar pinga... sempre ia buscar alguma coisa pra suprir a vendinha. Tinha um guarda, nem lembro o nome dele, era o guarda do CDS [Centro de Desenvolvimento Social]. Sempre nós íamos no ônibus juntos... Eu saía da minha casa e tinha de andar 40 minutos na estrada de terra pra pegar o ônibus pra conseguir chegar a Brazlândia... coincidia de eu ir com ele... Um dia eu ia passando na rua e ele chamou: Ô dona Maria, ô dona Maria!... Fui lá ver o que ele queria. O que foi seu Zé? Ele falou assim: Olha, amanhã vai começar a inscrição de lote, vem aqui pra senhora pegar a senha e pode vir bem cedo porque vai amontoar de gente.

No relato de Dona Maria, vemos o guarda como um mensageiro, cujo sinal marcou o início de uma real peregrinação dessa senhora em busca do seu lote.

Dona Maria: Cheguei em casa falei [para o marido]. E ele: Você vai? Eu tenho a minha inscrição, mas nunca saiu nada mesmo.

Aí eu levantei, fui no primeiro ônibus que tinha, cinco horas da manhã. Fui a primeira. Cheguei lá, fiz a inscrição. Depois, passou uns tempos: tem que renovar a inscrição [i.e. recadastrar].

Seu Vitório fizera sua inscrição para ganhar um lote há muitos anos, "mas", para ele, "nunca saiu nada". Muito provavelmente, Seu Vitório jamais tivesse conseguido um lote. O mesmo critério que fazia Seu Vitório despencar na classificação do governo, alçaria Dona Maria à condição de beneficiária: uma mulher solteira, mãe de alguns filhos, com todos os seus documentos transferidos para o Distrito Federal e com meios de comprovar o seu "Tempo de Brasília" reúne em si as condições ideais para "merecer" um lote.

Dona Maria: Conversei com a mulher [do CDS] e ela me disse: Se eu fosse você, eu tirava o seu cônjuge. Você tira o cônjuge e deixa só as crianças, porque fica mais fácil pra você ganhar. Eu fui e eliminei ele. Tirei ele fora... quer dizer, eu fiquei sendo mãe solteira e sem marido...

Dona Maria não era íntima da funcionária do CDS (órgão responsável pela triagem e cadastro das famílias). Não foi em troca de qualquer favor que a funcionária do CDS alertou Dona Maria para uma das variáveis que compunham a equação de pontuação dos inscritos: "nível salarial, número de dependentes, tempo de residência em Brasília, condição de ocupação da moradia, idade do cadastrado e, por fim, especificidades sociais" (Gonçalves 1998:101). Assim como o guarda do CDS, ela se permitiu interpelar Dona Maria de uma forma um tanto alheia ao procedimento burocrático ideal, "formal- 
mente igual para todos" (Weber 1993:180-181) ou à conduta patrimonialista habitualmente associada ao funcionário público no Brasil ${ }^{2}$.

Não havia nenhum laço forte entre eles que personalizasse as "dicas" que ambos lhe deram (a inscrição para o lote, a eliminação do cônjuge) e que a obrigasse a uma dívida para com os mesmos. Em cada encontro fugaz, ambos se permitiram aconselhá-la formas por eles conhecidas de se manejar "especificidades sociais".

As "especificidades sociais", se devidamente conduzidas, podem acelerar muito o processo de alguém que aguarda ser contemplado com um lote. No Recanto das Emas, em tom de pilhéria, de admiração ou mesmo de revolta, pipocam, aqui e ali, nas conversas do dia-a-dia, comentários sobre alguém que conseguiu reunir provas que "felizmente" o ajudaram a ganhar um lote ou, quando a pessoa contemplada não é benquista no círculo de conversas, como esta, mentindo, pôde ter alcançado tão facilmente um benefício que deveria ser concedido a pessoas verdadeiramente necessitadas e com "Tempo de Brasília"3. Embora a utilização de subterfúgios vários possa ser considerada legítima no processo de conquista de um lote, certas pessoas são desprezadas por suas "mentiras", ao passo que outras envolvidas com procedimentos igualmente ilegais (como a invasão de terras ou a adulteração de documentos) são admiradas por seu "conhecimento". A desqualificação, nesses casos, não se deve ao repúdio universal pela ilegalidade ou pela mentira, mas ao pouco prestígio social de quem recebeu o lote ${ }^{4}$.

Ao comparecer bem cedo para pegar a senha, Dona Maria foi lentamente incorporando esse novo conjunto de crenças. Atenta às sugestões recebidas, ela comparecia a todos os recadastramentos, reiterando o que foi se transformando em seu principal propósito, ganhar um lote:

Dona Maria: Sempre que era pra renovar eu corria atrás e renovava. Um dia, vim dar uma passeada aqui na Samambaia, porque tem uma irmã dele [do marido] que mora aqui. Ela falou assim: Maria da Glória do céu, eles estão transferindo lote, fazendo transferência de inscrição ou pra Santa Maria, ou pra Samambaia, ou pro Recanto das Emas, que eu nem sei onde é. Eu respondi: o quê? Eu nem fiquei direito na casa dela.

A notícia que Dona Maria recebeu de sua cunhada ("eles estão transferindo lote", isto é, o governo está distribuindo lotes, assentando inscritos) chega aos ouvidos dos moradores do Recanto das Emas de diversas formas. A mais corriqueira, no entanto, além do jornal, é o rádio, que todas as manhãs ecoa nos lares da cidade anunciando os feitos do governo e as próximas inaugurações de obras a serem "prestigiadas" pelo então governador 
Joaquim Roriz. Seja nas solenidades, seja em eventos cotidianos (como a fila para a entrega do pão e do leite, a fila no banco para o recebimento de um benefício com cartão magnético ou a fila para pedir algo ao administrador regional), agentes do governo tratam de transmitir informações a esse respeito aos presentes, os quais, por sua vez, se encarregam de propalar pelo Recanto as últimas notícias sobre os lotes.

Dona Maria: No outro dia cedo, eu me mandei pra casa, falei pra ele [para o marido], e ele: Você vai de novo? No outro dia de manhã, 5 horas da manhã, corri lá, na antiga SHIS, que agora é IDHAB. Quando cheguei lá - 8 horas abriu a porta —, o guarda perguntou: O que a senhora deseja? Eu falei: vim pra fazer transferência de inscrição. Aí ele disse: só 2 horas da tarde. Eu respondi: o quê? Eu com as minúsculas moedinhas na mão, porque o dinheiro pra pagar a passagem era de vale-transporte. Eu acho que eu não tinha 20 centavos na mão. Eu pensei: agora lascou, vou morrer de fome. Rodei, então, lá na W3 sul [avenida do Plano Piloto onde fica a Secretaria de Habitação], e achei uma padaria onde comprei um pão e fiquei lá, de castigo, até as 2 horas da tarde.

Cabe destacar que, a cada inflexão nos procedimentos relativos à obtenção de um benefício, se faz necessário o contato pessoal entre quem o demanda e os agentes do governo. É preciso que ambos se encontrem, sendo que os demandantes devem portar os documentos comprobatórios do que declaram para que os funcionários lhe entreguem um papel do mesmo teor. Por isso, Dona Maria deslocava-se para o Plano Piloto, pois é no Setor Comercial Sul, "lá na W3 sul", que se localiza o centro das decisões, a "antiga SHIS, que agora é IDHAB".

Quando o governo modifica as regras, o cadastrado deve, mostrando-se atento, comparecer aos órgãos competentes para se submeter aos novos parâmetros. Dona Maria revela-se familiarizada com tais alterações, a ponto de se lembrar da antiga SHIS (Sociedade de Habitações de Interesse Social Ltda.), que foi substituída pelo Instituto de Desenvolvimento Habitacional do Distrito Federal (IDHAB) no final do mandato de Joaquim Roriz como primeiro governador eleito do Distrito Federal (cf. Lei $n^{\circ} 804$, de 8 de dezembro de 1994). Esta mudança se deu no mesmo período em que Dona Maria se dedicava a garantir o recebimento de um lote.

Dona Maria: Aí foi amontoando gente, foi amontoando gente. Quando chegou a minha vez, eu falei pra moça: tem pra Samambaia? Intentando que eu vou ficar perto da minha cunhada. Samambaia não tem mais não. Mas tem Recanto das Emas e Santa Maria. Eu ficava cismada com Santa Maria. Santa 
Maria não quero não.

Antonádia: Por que?

Dona Maria: Não sei, eu não queria Santa Maria.

Seu Vitório: E ela não sabia do Recanto das Emas.

$[\ldots]$

Dona Maria: Eu nem conhecia o Recanto, menina.

Seu Vitório: Eu falei pra ela: Olha, você faz essa transferência pra Santa Maria, que seja pra onde for, mas faz a transferência. Se você chegar aqui sem essa transferência, nós vamos brigar. E ela: Eu, pra Santa Maria, eu não quero... Antonádia: O senhor queria pra Santa Maria?

Seu Vitório: Eu, uai, eu queria que fosse pra qualquer lugar.

Dona Maria: Ah, você pensou que eu não ia querer?!

Seu Vitório: Você já imaginou se ela não fizesse, se fosse pra Santa Maria e ela não fizesse? Quando ela chegou em casa e disse: eu consegui fazer pro Recanto das Emas, não sei onde é. Eu falei: Graças a Deus.

Dona Maria: E você sabia onde era?

Seu Vitório: Não...

Ao descreverem esse árduo dia, Dona Maria e Seu Vitório debatem sobre a "escolha" da cidade para onde transferiram sua inscrição, sem revelarem no entanto a que cidade sua inscrição inicial os destinava. Era início dos anos 90 e a "moça" do IDHAB apresentou-lhes o nome das cidades então recém-criadas pelo programa de assentamento para população de baixa renda. Dona Maria "cismou" com Santa Maria e transferiu sua inscrição para o Recanto das Emas. No relato do casal, essa decisão toma as feições de uma escolha, uma espécie de idiossincrasia a que se permitiram diante de um contexto pleno de constrangimentos exteriores ${ }^{5}$.

Dona Maria: Aí, toda vez que falavam: Roriz vai entregar lote no Recanto, eu me deslocava de pra lá de Brazlândia e vinha. Tirava uma xerox da inscrição, entregava, dava um jeitinho, punha na mão da secretária. Acho que eles enjoaram de tanto eu ir à SHIS e correr atrás deles. Acho que eles enjoaram: Não, dá logo a essa mulher, pra ficar livre dela logo.

É preciso perceber que Dona Maria apenas havia registrado em sua inscrição o desejo de receber do governo um lote na cidade do Recanto das Emas. Durante alguns anos mais ela precisou manter-se atenta. Sua assiduidade a colocava, em algumas ocasiões, na platéia de comícios do governador, quando ouvia o mesmo dizer que iria entregar mais lotes. Como Dona Maria, centenas de pessoas compareciam a essas solenidades e de lá saíam 
confortadas pelas palavras de Joaquim Roriz, que sempre expressava seu comprometimento pessoal com a distribuição de lotes para a população ${ }^{6}$. Este alento a tornava mais confiante na espera.

Se Dona Maria via e ouvia o governador, para garantir que sua urgência seria percebida, ela "tirava uma xerox da inscrição, entregava, dava um jeitinho, punha na mão da secretária". Este procedimento é bastante corriqueiro. Políticos e funcionários do governo do Distrito Federal costumam ser abordados por pessoas que lhes entregam esses tais papéis ${ }^{7}$. Por vezes sem timbre algum, escritos à caneta, frutos de cadastramentos constantes, tais pedacinhos de papel são carregados como amuletos, espécie de prova sagrada da participação de quem os porta no circuito de dons em que estão envolvidos o governo e a população local.

Neles constam o nome e o número de inscrição, ou seja, a senha que dá acesso ao cadastro oficial. A esperança de quem entrega o papel é que o político ou funcionário aprecie a contagem dos pontos e, se possível, ajude o inscrito a subir de posição no ranking. Essa longa espera pode um dia terminar com a melhor de todas as notícias: a contemplação com um lote ${ }^{8}$.

Antonádia: Aí um dia saiu o seu nome...

Dona Maria: Não é que saiu o nome no jornal! Mais ou menos eu já sabia. Uma vizinha lá falou assim: Como é que cê chama? Eu chamo Maria da Glória Alves do Nascimento. Ela falou: Não, Maria da Glória Alves (lembra, eu não era casada...). Meu pai falou que saiu a inscrição de lote, tem tanta Maria da Glória. Eu pensei então: Tenho fé em Deus que um é meu. Fiquei torcendo sem saber. Olha que eu já me arrepio de nervoso [mostra o braço arrepiado]. Meu Jesus vai abençoar que o meu lote tá lá. E nisso tem uma pessoa - que até é compadre da gente - tão assim desinteressada - eu fiz tudo pra ele fazer a inscrição e ele não quis - , que diz que lote saía só pra rico. Eu falei: Eu tenho fé em Deus, eu não sou rica, mas vou conseguir esse lote... Eu fui naquela expectativa: Eu não sei não, mas eu acho que o meu nome tá nesse jornal.

Seu Vitório: Eu comprei o jornal.

$[\ldots]$

Dona Maria: Quando ele chegou lá em casa, eu fui abrir a porta e lembrei: $M e u$ Deus. Ele falou: É, danada! Eu respondi: O que foi? O lote saiu! Aí, eu chorei. Chorei de alegria: Não acredito. E peguei meu marido e saí nas carreiras, no escuro, saí atropelando os paus, corri lá nesse compadre meu e falei assim: Compadre, eu não te falei? Que o lote não sai só pra rico? Eu sou pobre e ganhei, graças a Deus.

No relato de Dona Maria, parte fundamental da alegria de ter recebido o lote revelou-se na possibilidade de correr lá no seu compadre desinteres- 
sado e declarar: "Compadre, eu não te falei? Que o lote não sai só pra rico?". Ao contrário do que supunha seu compadre, ela tinha razão. Sua espera não tinha sido vã, e, a partir daquele momento, ela mesma poderia propagar o próprio sistema de crenças em que se envolveu. Laureada com o lote, Dona Maria correu até a casa de seu compadre e demonstrou o acerto de sua aposta, o enraizamento bem-sucedido de uma crença social da qual ele duvidava.

Dona Maria: E voltei correndo. No outro dia já vim, não, no outro dia não. Eles marcaram uma semana depois pra vir ver, sabe? Receber a inscrição, receber o papel, a documentação, para ter a posse.

Seu Vitório: No dia 14 de abril saiu no jornal, no dia 21 nós viemos aqui pra ver o lote.

Antonádia: Em que dia vocês se mudaram pro lote?

Dona Maria: No dia 21 a gente já veio de mudança. Pagamos, fizemos um frete de uma Brasília.

Antonádia: Dia 21. Vocês ficaram aqui, construíram...

Seu Vitório: Dia 21 nós saímos de lá e eu vim pra cá. Capinando e morando por aqui, mas a mudança mesmo só depois.

Dona Maria: E o medo? De alguém vir e entrar no lote? Porque tava uma invasão desgraçada.

Depois da publicação de seu nome (seu nome de solteira), não tardou para que Dona Maria recebesse "o papel, a documentação, pra ter pos$\mathrm{se}^{\prime \prime}$. O lote que receberam contemplou a vontade de ambos. Hoje a casa fica em uma rua e, virando a esquina, entra-se na barbearia de Seu Vitório. Em nossa conversa, Seu Vitório lembrou que nos primeiros meses em que esteve acampado no seu lote, capinou e fez fossa para os vizinhos. A mudança resumiu-se, inicialmente, à sua própria presença física no lote. Com o tempo essa atividade se esgotou e com os "500 cruzeiros" que conseguiu ganhar comprou "pinga, uns doces e seis copos". Onde nada havia, com a ocupação dos lotes, com os primeiros biscates, lhe foi possível uma certa acumulação primitiva. Aos poucos começaram a aparecer outros recém-chegados, os primeiros fregueses para a sua nova "vendinha". A pinga ia acabando e ele "corria pra comprar mais". Depois disso, cortou cabelo: "embaixo de qualquer sombra aí, eu cortava cabelo". Havia vizinhos que ao se estabelecerem por lá, como ele, passaram a precisar de seus serviços de barbeiro. Seu Vitório ficou sozinho até acreditar que poderia trazer seus filhos e esposa para o Recanto das Emas. Enquanto aguardava esse dia chegar os visitava em "pra lá de Brazlândia", no final de semana, "de pés". 
O desejo de Dona Maria, quando conversamos, era terminar sua casa: "Deus permita que eu tenha uma casa boa, bonita, com as minhas coisas bem bonitinhas. Porque o meu sonho é ter as coisas bem bonitinhas". Esta declaração alude à aspiração de possuir um conjunto de crenças coeso, que jamais pudesse ou voltasse a ser abalado por dúvidas alheias, exteriores. Um desejo por certo irrealizável que, ao mesmo tempo, é o que sustenta e constitui a atual crença de Dona Maria e Seu Vitório.

\section{Interregno}

A vida dos moradores do Recanto, como a deste casal, está repleta de índices que nos remetem às práticas governamentais nomeadas oficialmente como "política habitacional". Quando perguntadas sobre o lote, pessoas como Dona Maria e Seu Vitório nos respondem com uma verdadeira carta de navegação social. Suas crônicas servem para revelar não apenas a quem pergunta, mas também a quem responde, o itinerário que se percorreu até se alcançar o "Tempo de Brasília" — ou, de outro modo, como a areia desse "Tempo de Brasília" escorreu e se acumulou no interior de cada um, como se cada indivíduo fosse uma ampulheta medindo a si próprio.

A compreensão desse "mecanismo" por parte dos moradores do Recanto das Emas, como Dona Maria e Seu Vitório, não é de uma falácia post hoc ${ }^{10}$. Ao recuperar os passos de sua peregrinação em busca do lote, Dona Maria sublinha categorias e procedimentos que estão difundidos "horizontal" e "verticalmente" (se nos é permitida essa analogia tridimensional do espaço social), não apenas entre os moradores do Recanto das Emas, mas também entre os agentes do governo, que os transmitem às pessoas comuns.

Os eventos rememorados com ênfase não estão concatenados de uma certa maneira por acaso. A forma como Dona Maria dispõe os fatos passados obedece a um conjunto de pressupostos conhecido por todos - até mesmo por aqueles que se recusam a trilhar esse caminho (como seu "compadre desinteressado"). Não se trata de uma narrativa sui generis ou uma saga particular, mas de uma objetivação relativa a uma prática comum a todos os moradores do Recanto das Emas com quem convivi. Prática esta marcada por uma série de procedimentos obrigatórios: as madrugadas nas filas, o cadastramento, a atualização periódica do cadastro, o conhecimento gradual das variáveis que "pesam" na fórmula que calcula a pontuação do candidato, a adequação entre os dados de que se dispõe e aqueles que devem ser apresentados ao governo, a procura de documentos que registrem a veracidade do que é declarado, a angustiante espera pela contemplação, interca- 
lada por frustradas espiadelas no Diário Oficial e nos jornais, e, enfim, o nome na lista - a emoção inenarrável dessa experiência, a ocupação do lote, a construção de um barraco e, mais uma vez, a espera pela escritura.

\section{As fórmulas}

Brasília, como sabemos, trata-se de uma invenção demiúrgica do governo de Juscelino Kubitschek. Naquela ocasião, o governo, depois de desapropriar, loteou e vendeu as terras do atual Distrito Federal ${ }^{11}$. Para fazê-lo, especialmente em se tratando dos loteamentos populares, foram sendo estabelecidos critérios capazes de definir os potenciais beneficiários dessa dádiva estatal. Em 1958, por exemplo, o serviço social da Novacap indicava se os trabalhadores desejosos de adquirir um lote na primeira cidade-satélite (Taguatinga) estavam "habilitados" para pagar as futuras prestações (Oliveira 1987:133), concedendo prioridade aos pedidos de trabalhadores candangos, isto é, empregados na construção civil (Ribeiro 1980).

Já nesses primórdios, para além da mera solvência financeira, critérios envolvendo legitimidade e precedência determinavam quem seriam os primeiros agraciados com as políticas habitacionais do governo. Quem não estivesse em Brasília trabalhando em empregos formais (p.ex. ligados à construção civil) não poderia comprar um lote do governo. Banidas dessas primeiras vendas de lotes, inúmeras famílias capitanearam as primeiras invasões de terras no Distrito Federal.

Esse mecanismo incidia de modo semelhante na concessão de benefícios imobiliários do governo para funcionários públicos que desejassem viver em Brasília. Em 1961, a Novacap calculava, por exemplo, quanto um funcionário merecia tornar-se inquilino de um imóvel do governo no Plano Piloto a partir do tempo dedicado à sua função (ou seja, ao Estado), do salário que recebia, do número de dependentes a ele ligados e do cargo que exercia:

[...] cada período de 4 meses de exercício efetivo - 01 ponto ... salário até Cr\$ 15.000 - 01 ponto; de Cr\$ 15.000 a Cr\$ 25.000 - 02 pontos; acima de Cr\$ $25.000-03$ pontos ... cada dependente $-1 / 5$ ponto ... chefe de departamento e chefe de gabinete - 03 pontos; chefe de divisão e de gabinete de diretor 02 pontos; chefe de serviços e de seção — 01 ponto (Bertone 1987:55).

Os invasores, ignorados inicialmente por não se tratarem nem de pioneiros, nem de candangos ${ }^{12}$, passaram gradualmente a ser também alvo da atenção classificatória governamental ${ }^{13}$. Inúmeros foram os cálculos 
propostos por engenheiros sociais para hierarquizar essa vasta parcela de pessoas que vivia no limbo das invasões. Aqueles que tivessem "Tempo de Brasília" e demonstrassem ser mais necessitados concorreriam pela distribuição de lotes e de outros benefícios. A legitimidade classificatória estatal estabeleceu-se lentamente, por meio do uso de categorias reconhecidas localmente como definidoras de méritos, dentre as quais se destacava o tempo vivido na nova capital.

A atribuição de pontos a cada conjunto de atributos (anos vividos em Brasília, situação socioeconômica etc.) foi sendo aprimorada até tornar-se trivial a avaliação desse mérito por intermédio de equações. Por meio de fórmulas, passou-se a calcular o quantum de merecimento dos inscritos nos diversos programas assistenciais do governo, prática esta que se tornou corrente.

O poder estatal em questão não se restringia apenas à doação de lotes, mas à classificação da população entre mais e menos apta a se tornar beneficiária. Quem se relacionava com o governo por meio dessas modalidades de assistência tinha, como vimos no caso de dona Maria, seu nome estampado em listas. O recebimento do lote dependia - ao menos em tese — da colocação obtida na lista, e essa ordem, por sua vez, era estabelecida mediante a soma dos pontos alcançados por cada indivíduo.

De todos os componentes da equação, ao tempo de residência no Distrito Federal era dado um grande destaque e valor, como se a vida na capital ungisse certas pessoas com uma qualidade especial, expressa por meio da categoria "Tempo de Brasília". Quem não nasceu na capital federal, ou seja, quem não é "filho de Brasília", precisa passar necessariamente por cinco anos de provação para tornar-se digno dos diversos benefícios ofertados pelo governo local. Esse tempo mínimo estabelece uma hierarquia a que praticamente toda a população "de baixa renda" se submete de igual maneira.

Um sistema de classificação que procura ordenar a população a partir de um conjunto de méritos (estabelecidos e controlados pelo governo) faz sentido especialmente quando aquilo que o governo oferece não pode ser doado de forma universal e equânime a todos. Cada fórmula criada, como veremos, dispõe de um conjunto de variáveis que se pretendem as mais precisas para calcular o grau de merecimento da população em face dos bens (raros) a ela disponibilizados pelo governo. A razão de ser dessas fórmulas (hierarquizar os inscritos diante de um bem limitado) continuou a mesma ao longo dos anos, porém, seu conteúdo sofreu diversas alterações devido a mudanças nos juízos acerca do conjunto de méritos considerados os mais reveladores de qualidades que destacariam alguns como merecedores de dádivas que não podem ser universalmente ofertadas. 
Por esse motivo, julgo importante acompanhar as modificações mais bruscas dessas fórmulas nos últimos anos, bem como as categorias que permanecem atuantes em todas elas, para percebermos quais são os atributos básicos exigidos de todos os futuros beneficiários e quais são as qualidades que esclarecem as razões pelas quais o governo entra em contato e se mantém próximo de uma parcela, e não de toda a população que demanda atenção pública no Distrito Federal.

\section{Primeira Fórmula: o cadastro geral}

Uma legislação emblemática, dedicada à sistematização de critérios capazes de tornar passíveis de cálculo a ancestralidade e a legitimidade de alguém como merecedor de um lote doado pelo governo, remonta os idos da década de 80. No governo de José Aparecido de Oliveira foi decretado, no dia 5 de janeiro de 1986 (Decreto $\mathrm{n}^{\circ}$ 10.056), o cadastro geral de pretendentes à moradia no Distrito Federal, que tomava o lugar do "antigo Sistema de Inscrições", inalterado durante todo o período de ditadura militar.

Naquela ocasião, o órgão responsável por essa matéria era a SHIS (Secretaria de Habitação e Interesse Social). Para entrar na competição, qualquer indivíduo deveria preencher certos "requisitos básicos": não ter sido proprietário de ou não ter imóvel no Distrito Federal, ser maior de 21 anos, ter todos os seus documentos em dia, preencher os cadastros necessários, cumprir os prazos estabelecidos e, condição sine qua non, "ser residente e domiciliado no Distrito Federal, comprovadamente, há mais de cinco anos". Esses cinco anos passaram, desde então, a ser referidos, nos próprios documentos oficiais, como "Tempo de Brasília". Já, quando conclamado, o indivíduo deveria "comprovar renda familiar mínima compatível com o encargo mensal". No mesmo decreto $\left(\mathrm{n}^{\mathrm{O}}\right.$ 10.056) é exposta a fórmula de classificação adotada:

$$
\begin{aligned}
& \mathrm{P}=(\mathrm{a}+2 \mathrm{~b}+\mathrm{c}) \mathrm{d}+4 \mathrm{e}+8 \mathrm{f} \\
& \text { onde, } \\
& \mathrm{P}=\text { total de pontos obtidos pelo candidato }{ }^{14} \\
& \mathrm{a}=\text { faixa etária do candidato (exposta em uma tabela) } \\
& \mathrm{b}=\text { número de dependentes } \\
& \mathrm{C}=\text { candidato com deficiência física } \\
& \mathrm{d}=\text { idade média da família } \\
& \mathrm{e}=\text { tempo de inscrição } \\
& \mathrm{f}=\text { dependente inválido }
\end{aligned}
$$


Tanto o número de membros da família quanto a idade dos mesmos só poderiam ser comprovados por meio de certidões oficiais; também a eventual deficiência física de um familiar deveria ser demonstrada com atestado médico oficial. A partir desse decreto, a contemplação passou a ser comunicada ao candidato inscrito via edital público. Essa forma de proceder (por meio de critérios padronizados a que se submeteriam todos os inscritos em um cadastro geral) se naturalizou lentamente como modo de documentar, ordenar e calcular eventos vividos em Brasília e, o que é fundamental, tanto por parte dos agentes do governo quanto pelo lado da população envolvida.

\section{Segunda Fórmula: a renda}

Passada mais de uma década do governo de José Aparecido, em 3 de julho de 1997, o segundo governador eleito do Distrito Federal, Cristovam Buarque, estabeleceu outra expressão para classificar os "candidatos aos programas de assentamento de população de baixa renda":

$$
\mathrm{P}=\mathrm{C}+\mathrm{D}+\mathrm{M}+\mathrm{T}+\mathrm{I}+\mathrm{N}+\mathrm{F}+\mathrm{R}
$$

Em quadros anexos ao decreto, eram exibidos quantos pontos se obteria por deficiência física (C), pelo número de dependentes (D), pela condição de moradia (M), pela idade média $(F)$ e renda da família $(R)$, pelo tempo de permanência no Distrito Federal (T), pela idade (I) e naturalidade (N) do candidato. Caso "ocupasse uma sub-habitação", o candidato obtinha 100 pontos, ao passo que um candidato inquilino apenas 60 pontos. A tabela, que atribuía pontos de modo inversamente proporcional à renda familiar, variava de menos de 1 salário mínimo a 10 salários mínimos - dentro desse intervalo se encontrava a "população de baixa renda"15. Quem "tivesse permanecido" há somente cinco anos (tempo mínimo necessário à inscrição) no Distrito Federal não recebia ponto algum. No quadro onde se definem estes últimos pontos, o cume é alcançado por quem demonstra viver há mais de 30 anos no Distrito Federal - ou seja, 100 pontos para aqueles que desde 1957 estivessem em Brasília. O candidato "natural" do Distrito Federal recebia 100 e aqueles de "outras unidades da Federação", por sua vez, 20 pontos.

\section{Terceira Fórmula: a lista limpa}

Vemos que as categorias básicas permanecem intocadas, sendo o cálculo 
complexificado apenas pelo uso de tabelas anexas. Imerso na lógica local que considera o tempo vivido no Distrito Federal como um atributo que distingue os moradores entre si, esse modelo indica o enraizamento dessas categorias fundamentais acionadas pelo governo para ordenar a população. Como uma das últimas realizações daquele governo no âmbito da política habitacional, em 6 de março de 1998, foi instituído, por meio de um outro decreto (no 19.074), o "Programa Morar Legal — Lista Limpa"16.

Em alusão explícita à sujeira que poluía o IDHAB e suas deliberações até então, foi formulada uma nova expressão de cálculo classificadora de quem ansiava por um lote ou por uma casa "ofertada" pelo governo. A fórmula destinava-se a hierarquizar os inscritos em uma lista que fosse, desta feita, "limpa". Nessa equação temos:

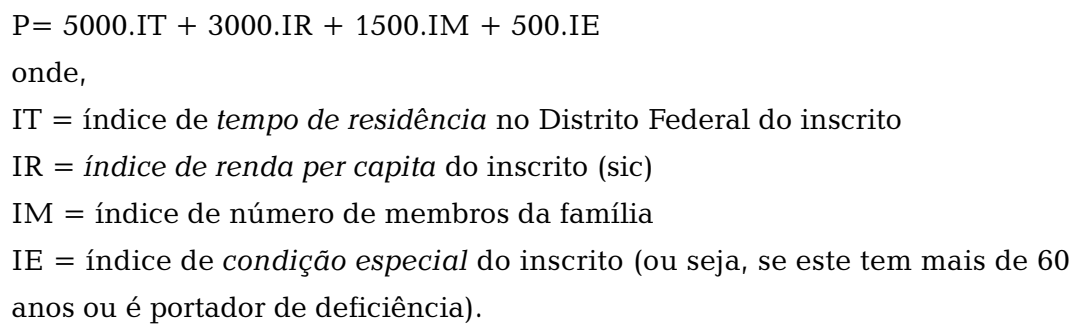

Esta fórmula sinaliza uma importante guinada no padrão de cálculo do governo. Sem questionar a classificação em si, ou seja, a possibilidade de se ordenar a população ansiosa por um benefício, essa nova fórmula reitera tal poder governamental, concedendo um peso ainda maior ao "tempo" do candidato em Brasília. O "tempo de residência no Distrito Federal" é alçado a fator determinante na corrida pelo benefício (multiplicado por 5000).

\section{Quarta fórmula: o núcleo familiar}

No último governo de Joaquim Roriz (1999/2002), uma outra mudança ocorreu. Como forma de marcar as diferenças entre os governos, o IDHAB foi substituído pela Secretaria de Estado de Desenvolvimento Urbano e Habitação (SEDUH). Sob a batuta de um novo governo e de um novo secretariado, não foi somente o órgão voltado para a habitação que mudou de nome e sigla; uma nova fórmula também foi criada:

$\mathrm{P}=\mathrm{Cnf}+\mathrm{Ndf}+\mathrm{Tdf}+\mathrm{Ces}+\mathrm{Min}$

onde, 
$\mathrm{Cnf}=$ ao número de componentes do núcleo familiar. Numa tabela progressiva ficamos informados de que uma família com um membro recebe 100 pontos e uma com sete pessoas 3000 pontos, por exemplo.

Ndf = aos componentes do núcleo familiar nascidos no Distrito Federal. Consultando a tabela, sabemos que uma família com sete membros nessa condição recebe 2400 pontos, por exemplo.

Tdf = ao tempo de moradia no Distrito Federal; calculado de forma ainda mais complexa, através da multiplicação do número de dias (sic) por um fator disponibilizado também em uma outra tabela progressiva.

Ces $=$ aos portadores de condições especiais, sendo que cada membro da família considerado desta forma acrescenta 10 pontos a mais no cálculo geral.

Min = à média aritmética da idade dos componentes do núcleo familiar considerado.

A nova fórmula continuou recorrendo a fatores e a progressões oferecidos por tabelas anexas, de complicado uso para boa parte dos moradores do Recanto que conheci interessados em calcular seu "Tempo de Brasília". Esse procedimento se estabeleceu, assim, gradualmente, como natural para determinar a pontuação e a conseqüente classificação dos candidatos em listas. Dificuldade essa que adensava ainda mais com as freqüentes visitas aos órgãos competentes necessárias para a atualização cadastral dos inscritos - afinal, cada "mudança na vida", como o nascimento de um filho, ou, por fim, a própria passagem dos anos no Distrito Federal, reconfiguravam as condições de disputa do candidato ao lhe acrescentar ou, eventualmente, subtrair "pontos".

Esse desdobramento aparentemente mecânico da equação indica uma significativa mudança na forma de compor a legitimidade ou o grau de merecimento a ser imputado ao futuro beneficiário do governo. A mera existência de um índice geral denuncia o alastramento de uma concepção segundo a qual todos podem ser "calculados" a partir de um parâmetro comum. Chama a atenção nesta última fórmula, ainda, a distinção que se faz entre as pessoas nascidas no Distrito Federal e as que apenas viveram em Brasília. Pela primeira vez, vemos serem contemplados de forma diferenciada aqueles que nasceram no Distrito Federal. Embora a categoria pioneiros ou candangos tenha surgido com Brasília, essa nova variável nos remete às gerações que nasceram em Brasília, isto é, em uma cidade já estabelecida ${ }^{17}$.

Vemos desta feita o "núcleo familiar" como fornecedor das bases para o cálculo e não apenas o inscrito, como na equação anterior.

Nesse sentido, o conjunto de membros de uma família, com seu "Tempo de Brasília" e suas agruras coletivas somadas, pode alçar o candidato a um 
lote, por exemplo, a uma posição mais avançada na lista de quem aguarda ser contemplado. No entanto, para fornecer todas as informações a respeito de cada membro da família ou do "núcleo familiar", exige-se do inscrito um comprometimento ainda maior em reunir um conjunto de documentos comprobatórios autênticos. Os sacos plásticos ou as caixas de papelão plenos de documentos, tão comuns no Recanto das Emas, simbolizam tanto o controle e a importância que um certo indivíduo tem para um grupo de pessoas que o cerca - sua família - como o controle e a importância que o governo tem para esse indivíduo. Se o "núcleo familiar", procurando comprovar seu "Tempo de Brasília", ao dar mostras de sua unidade, cria essa unidade, também o governo, ao dar e exigir reiteradamente provas documentais de sua relação com a população, cria essa relação.

\section{O sentido das fórmulas}

Além desses decretos colhidos para ilustrar tal processo, muitos outros tiveram lugar, acrescentando, aqui e ali, pequenas mudanças na legislação e pari passu na conduta coletiva em relação a esse fenômeno. O que pretendo fixar, a partir das mudanças classificatórias promovidas pelo próprio governo, é o efeito que essa legislação tem sobre a realidade local. Por um lado, tais transformações são implementadas tendo como esteio alterações nos "padrões" de migração, moradia e natalidade que se detectam via "pesquisas" realizadas pelo próprio governo, por meio dos diversos cadastros preenchidos pela população e também pelos dados censitários. Por outro, a própria população tem suas crenças e condutas (ou seja, seu hábito) fortemente orientadas pela legislação e políticas públicas locais - como foi possível perceber pelos percalços passados por Dona Maria.

Ao recuperarmos algumas das equações criadas pelo governo local, compreendemos gradualmente a que se refere cada parte dessas sentenças (ou seja, cada variável) e por que as mesmas foram destacadas do repertório classificatório nativo para figurar em uma fórmula mágica estatal, tornando-se logo em seguida categorias legais de referência para a população. Esse movimento espiralado, que conduz o poder estatal ao encontro do cotidiano da população e vice-versa, indica a construção da gramaticalidade dessa relação de troca em que se intercambia o tempo pelo espaço, os anos vividos e sofridos em Brasília por um lote — ou, em última instância, por um lugar social.

Portanto, menos que tomar as fórmulas e os conceitos governamentais de maneira referencial, o que julgo revelador é o sentido do processo histórico 
ao qual essas mudanças aludem, ou seja, a alterações nos hábitos — tanto do governo, quanto da população - que sustentam essa classificação.

\section{Conclusão}

Como vimos, o "Tempo de Brasília" não se refere apenas aos anos vividos na capital, mas à capacidade de ter suportado, ano após ano, agruras de toda ordem e, mais ainda, à habilidade em comprovar esses dissabores por meio de documentos cujo emblema e garantia é, por sua vez, um papel com o número da inscrição que todos trazem consigo. Na conversa com Dona Maria e Seu Vitório, vimos como as alterações formais das regras burocráticas se replicam nas experiências sociais concretas dos indivíduos que pleiteiam um lote ou outros benefícios do governo local. Trata-se de um modelo ritual de trocas - entre as pessoas do governo e as pessoas do Recanto das Emas vivido cotidianamente por meio dessa distribuição de bens governamentais que garantem a fixação da população a lugares outrora inexistentes que, assim, vão sendo gradualmente transformados e compreendidos como espaços controlados pelo Estado (Franco 1983).

Além de ser um conceito relativo a algo cronológico, isto é, à "criação de intervalos na vida social" (Leach 1974:207), o "Tempo de Brasília" refere-se à conformação daquilo que procurei chamar, inspirada em Charles Peirce, de comunidade de crença (Peirce 1992:149). Ao longo de cinco anos ou mais, em vários locais do Distrito Federal, milhares de pessoas aguardam por essa metamorfose social que lhes ungirá com o "Tempo de Brasília", necessário ao recebimento de um lote. Nessa espera, a própria crença na espera é conformada e com ela a aceitação coletiva de um hábito . Enquanto aguardam pelo dia em que terão "Tempo de Brasília", as raízes dessa crença vão penetrando lenta e profundamente nos indivíduos.

Em uma invasão, ao lado de outros invasores, ou em um barraco, ao lado de outros barracos, enquanto esperam os sujeitos se vêem espelhados em seus colegas e vizinhos. A espera de uns reforça a dos outros e as dúvidas que assomam tendem a ser espantadas para longe. Sem perceber, como Dona Maria, as pessoas passam a ter seu "Tempo de Brasília" quando aprendem a manipular as fórmulas que o governo supõe como emblemáticas e fidedignas do modo de vida da população. Para outras tantas, porém, os anos correm sem que elas jamais tenham "Tempo de Brasília", sem que elas consigam se inserir nessa comunidade de crença. Não que os primeiros se tratem de sujeitos meramente alienados, manipulados por políticos. O diferencial de poder 
existe e pende para o lado dos governantes. No entanto, como podemos compreender a partir da experiência emblemática de Dona Maria e seu marido, essa ligação dos políticos com quem vota neles não se justifica pela mera troca de favores (rotineira ou esporádica), mas pelo compartilhamento de um hábito, de um conjunto de crenças. É dessa forma que se dá o exercício do poder, não por um simples dom carismático de Roriz ou de outro político qualquer, não pela ignorância atávica de um povo cujo caráter é marcado por relações de subordinação a seus patrões, mas pela gradual inculcação da lógica burocrática dos governos no cotidiano de todos nós ${ }^{19}$.

As inúmeras fórmulas, suas infindáveis alterações, exigem dos que demandam qualquer benefício (considerado, paradoxalmente, público, mesmo que não oferecido de maneira universal e equânime) um envolvimento constante com os agentes do governo. Como ouvi certa vez no Recanto, não se trata de ser um seguidor cego de Roriz, mas de ser um adepto, ou seja, alguém assíduo, constantemente presente. É por meio desse envolvimento visceral com o governo que o Estado se faz presente - e, literalmente, logicamente indispensável - na vida das pessoas. Não por causa de uma noção universalista, democrática de direitos - como gostariam alguns -, mas por uma necessidade (sócio-)lógica. No Recanto das Emas, depois de iniciado esse vínculo, depois de inscrito, qualquer sujeito passa a pensar e a agir sobretudo em relação ao governo.

O "Tempo de Brasília" diz respeito preponderantemente à profundidade e à extensão desse envolvimento mútuo entre o governo e as pessoas. Individualmente, há muitos que duvidam da doação de lotes, da espera pela contemplação. No entanto, essas dúvidas não chegam a abalar a comunidade de crença produzida pelo sem-número de ações diárias que põem em contato as pessoas comuns e os agentes do governo, os primeiros com suas vidas em mudança e os últimos com as mais recentes exigências, os mais novos critérios classificatórios do governo. Mais que um item de uma equação estabelecida por engenheiros sociais, o "Tempo de Brasília" seria ele próprio uma fórmula sintética derivada da vida neste lugar, caracterizada pela presença do governo no cotidiano de todos.

Recebido em 16 de fevereiro de 2004

Aprovado em 20 de janeiro de 2005

Antonádia Borges é professora e pesquisadora PRODOC-CAPES no PPGAS/MN/UFRJ. E-mail: <antonadia@uol.com.br> 


\section{Notas}

* O presente artigo é uma versão modificada de Borges (2004).

${ }^{1}$ Os moradores do entorno, não raro, pedem emprestado a alguém próximo, morador do Distrito Federal, um comprovante de residência. Residir em Brasília, mesmo que de modo fictício, facilita diversos trâmites, sobretudo aqueles relativos à obtenção de benefícios públicos. Da mesma forma, os políticos da capital nutrem um interesse especial por esses moradores do entorno. No Recanto das Emas corria um boato que um senador, proprietário de uma construtora, exigia que seus funcionários tivessem um endereço e um título eleitoral no Distrito Federal, mesmo que residissem, de fato, em alguma cidade de Goiás, para poder votar nele.

${ }^{2}$ Candido dedica-se à investigação da trajetória de "um burocrata imperial que saiu do nada" (2002:13) para demonstrar a heterogeneidade do que se nomeia funcionalismo público. A história do Senhor Tolentino seria uma exceção à regra amplamente aceita, que diz: "A nossa tradição administrativa provém da ibérica, na qual o cargo conservou o caráter de prebenda. Tradição no fundo mais próxima das concepções orientais, que ligam o ato administrativo à propina, do que da concepção alemã de inspiração luterana, segundo a qual o serviço público é missão." (Candido 2002:90)

${ }^{3}$ No Recanto das Emas é muito comum que sejam construídas duas ou três residências em um mesmo lote. Nessas situações, em geral, é preciso que exista um acordo sobre a divisão de tarifas de água ou luz, por exemplo. Ou mesmo sobre a divisão das despesas com o material necessário para que se faça um gato, uma gambiarra (ligação clandestina). Este costuma ser um motivo para desavenças. As discussões têm como ápice um momento de ameaça, que diz respeito à veracidade das informações que o oponente apresentou aos órgãos do governo. Em um caso registrado na delegacia de polícia, uma mulher lembra-se de ter ameaçado o vizinho inconveniente: "você está aqui porque é mentiroso, eu vou falar no IDHAB que você mora sozinho, não tem nada de família, pra você parar com esse abuso."

${ }^{4}$ Elias e Scotson interpretam de forma semelhante a dupla valência da fofoca. Em "Winston Parva" o mexerico poderia ser bem-vindo, se a fofoca fosse conduzida por pessoas com afinidades. Esta seria a chamada pride gossip. No entanto, quando grupos beligerantes lançavam mão de rumores, estes eram percebidos como recurso de difamação, ou seja, blame gossip. A fofoca tinha, portanto, tanto "a função de apoiar as pessoas aprovadas pela opinião dominante", quanto de "excluir e cortar relações." (2000:125) 
${ }^{5}$ Um processo social aparentemente unívoco, quando descrito com categorias antagônicas, releva os paradoxos vividos pelos envolvidos. Entre os trabalhadores da cana pesquisados por Sigaud, eram acionadas duas justificações para suas demissões: terem sido "botados para fora" ou terem saído por "gosto e vontade". Por meio de ambas, dependendo do grau de assimetria em sua relação com o patrão, o trabalhador poderia expressar sua "ida para a rua" (1979:197, ênfase no original).

${ }^{6}$ Em um dos comícios que eu própria assisti, pude ouvir o governador declarar: "Eu gostaria de ter arranjado um lote muito grande para vocês. O Brasil é o maior país do mundo. Não é direito que cada um não tenha o seu pedacinho de chão."

${ }^{7}$ Papéis, em um sentido lato, seriam considerados documentos também nesse contexto (Peirano no prelo), a ponto de impressos de outras ordens, como notas fiscais, por exemplo, poderem servir como comprovante do tempo de fixação daquela pessoa à capital federal. Em outro âmbito, relativo a invasões de terra capitaneadas por camponeses, Hobsbawm retrata a importância de se portar pequenos pedaços de papel indicativos do direito à terra: "Possuir papelitos é muito importante para a comunidade camponesa latinoamericana. Reais ou forjados os mesmos são cuidados, preservados, escondidos de possíveis ladrões pois perdê-los afetaria seus direitos de alguma forma, mesmo que não se possa dizer que a perda dos papelitos enfraqueceria seu sentido de existência." (Hobsbawm 1974:125)

${ }^{8}$ A cada nova eleição com troca de governo há uma enorme alteração no quadro de funcionários. Esta mudança tem um efeito contundente na vida daqueles que peregrinam pelos corredores com papéis que os lancem à classificação necessária para ganhar um lote ou daqueles que montam seus barracos em áreas proibidas aguardando uma remoção seguida de assentamento. Quando a pessoa com quem se tratava, em quem se confiava, "desaparecia", tudo poderia recomeçar do zero. O papelzinho, nestes casos, representava a prova material de um elo que, não raro, além de inócuo poderia ser malvisto pelos recém-eleitos, já que simbolizava o governo anterior.

9 "Apesar de não ter sido publicado, no decreto de criação do Programa [de Assentamento de População de Baixa Renda] foi estipulado o prazo de 3 (três) dias para os favelados construírem seus barracos e o de 45 (quarenta e cinco) dias para os inquilinos [caso de Dona Maria] ocuparem seus lotes. Decorrido o prazo, desde que justificado, havia uma prorrogação e posteriormente a retomada dos lotes para serem redistribuídos" (Gonçalves 1998:101).

10 "O evento inaugural a possibilidade de uma crônica e a crônica, embora possa não ser história, fornece o pergaminho sobre o qual o histórico (e mesmo uma história não narrativa) pode ser escrito." (Daniel 1996:50) 
11 "Desapropriadas as fazendas dentro das fronteiras do Distrito Federal, e passadas as terras para o patrimônio da Novacap (Companhia Urbanizadora da Nova Capital), passou o Estado, proprietário fundiário, a loteá-las e vendê-las." (Oliveira 1987:130)

12 Para uma interpretação dos significados dos termos "candango" e "pioneiro" ver, especialmente, Laraia (1996). Nos documentos oficiais, o pioneiro é definido como aquele que "fixou residência ou domicílio em Brasília até 1970".

${ }^{13}$ No primeiro governo de Joaquim Roriz (durante o regime militar, quando esses cargos eram ocupados por governadores indicados, ditos "biônicos") foi decretado o "programa de assentamento de população de baixa renda" (Decreto $\mathrm{n}^{\circ}$ 11.476, de 9 de março de 1989).

${ }^{14}$ No Recanto das Emas, a idéia de ser candidato é assim alastrada, para além do universo dos políticos profissionais. As pessoas candidatam-se a um lote, a uma cesta básica. Se bem colocadas no ranking, são eleitas. Uma senhora, cabo eleitoral de Joaquim Roriz, declarou ter sido "eleita para um emprego" quando aquele foi eleito governador e ela indicada para um cargo comissionado.

${ }^{15}$ É interessante notar que, ainda no governo de Cristovam Buarque, esse teto se elevou - "A família de baixa renda, para efeito desta lei, é aquela cuja soma dos ganhos de todos os seus integrantes não ultrapassa a doze salários mínimos" (conforme a Lei $\mathrm{n}^{\circ} 2.130$, de 12 de novembro de 1998) - , indicando que um aumento no espectro dos prováveis beneficiários não abarcava somente a população de renda mais baixa.

16 "O programa 'Brasília Legal', ao propor um legalismo exacerbado e reprimir, de forma violenta, os setores populares de ocuparem terras sem uso, acaba por beneficiar a população mais rica que se apropria da terra e garante, por meio da lei e de seus advogados, o lucro fácil, enquanto o trabalhador é removido pela polícia para localidades distantes ou simplesmente fica ao desabrigo" (Gouvêa 1999:269).

17 Para uma discussão da categoria "filho do município" em outros contextos etnográficos, ver Peirano (1986).

18 "A crença [...] é um hábito da mente essencialmente persistente por algum tempo, e em grande parte (ao menos) inconsciente como outros hábitos é (até encontrar algo que a surpreenda e comece a dissolvê-la) perfeitamente auto-satisfatória. A dúvida [...] não é um hábito, mas a privação de um hábito." (Peirce 1998:337).

19 Guardando as devidas e importantes singularidades de cada caso, não se 
trata de merca coincidência que Strathern e outros percebam em outros âmbitos (por vezes bastante próximos à academia) um processo análogo que nomeiam como "culturas da auditoria" (audit cultures)

\section{Referências bibliográficas}

BERTONE, L. F. 1987. "O Estado e a urbanização do Distrito Federal". In: A. Paviani (org.), Urbanização e metropolização: a gestão dos conflitos em Brasília. Brasília: Edunb/ CODEPLAN. pp. 51-72.

BORGES, A. 2000. "Os signos de uma invasão: espaço e política no Distrito Federal". Série Antropologia, 283:11-26, Brasília.

2003. Tempo de Brasília: etnografando lugares-eventos da política. Rio de Janeiro: Relume Dumará. 2004. "A fórmula do tempo: notas etnográficas sobre o 'Tempo de Brasília"'. In: C. C. Teixeira e C. de A. Chaves (orgs.), Espaços e tempos da política. Rio de Janeiro: Relume Dumará/NuAp. pp. 23-46.

CANDIDO, A. 2002. Um funcionário da monarquia: ensaio sobre o segundo escalão. Rio de Janeiro: Ouro sobre azul.

DANIEL, E. V. 1996. Charred Lullabies: chapters in an anthropography of violence. Princeton: Princeton University Press.

ELIAS, N. e SCOTSON, J. L. 2000. Estabelecidos e outsiders. Rio de Janeiro: Jorge Zahar.
FRANCO, M. S. de C. 1983. Homens livres na ordem escravocrata. São Paulo: Kairós.

GONÇALVES, M. da C. V. 1998. Favelas teimosas: lutas por moradia. Brasília: Thesaurus.

GOUVÊA, L. A. de C. 1999. "Uma política habitacional de interesse social para o Distrito Federal". In: A. Paviani (org.), Brasília - gestão urbana. Conflitos e cidadania. Brasília: Editora Universidade de Brasília. pp. 253-270.

HEREDIA, B. e PALMEIRA, M. 1995. "Os comícios e a política de facções". Anuário Antropológico/94. Rio de Janeiro: Tempo Brasileiro. pp. 31-94.

HOBSBAWM, E. J. 1974. "Peasant land occupations". Past and Present, 62:120-152.

LARAIA, R. de B. 1996. "Candangos e pioneiros". Série Antropologia, 203. Brasília.

LEACH, E. R. 1974. "O tempo e os narizes falsos". In: Repensando a antropologia. São Paulo: Perspectiva.

LEAL, V. N. 1949. Coronelismo, enxada e voto: o município e o regime representativo no Brasil. São Paulo: Nova Fronteira. 
OLIVEIRA, M. L. P. 1987. "Contradições e conflitos no espaço". In: A. Paviani (org.), Urbanização e metropolização: a gestão dos conflitos em Brasília. Brasília: Edunb/CODEPLAN. pp. 125-144.

PEIRANO, M. 1986. "Sem lenço, sem documento". Sociedade e Estado, 1(1):49-63.

.(no prelo). "De que serve um documento?". In: C. Barreira e M. Palmeira (orgs.), Política no Brasil: visão de antropólogos. Rio de Janeiro: Relume Dumará.

PEIRCE, C. S. 1992 [1878]. "The doctrine of chances". In: N. Houser e C. Kloesel (eds.), The essential Peirce volume 1. Bloomington: Indiana University Press. pp. 142-154. 1998 [1905]. "What pragmatism is". In: N Houser e C. Kloesel (eds.), The essential Peirce volume 2. Bloomington: Indiana University Press. pp. 331-345.
QUEIROZ, M. I. P. de. 1969. O mandonismo local na vida política brasileira (da colônia à primeira República). São Paulo: Instituto de Estudos Brasileiros.

RIBEIRO, G. L. 1980. "A capital da esperança" - Brasília: um estudo sobre a grande obra da construção civil. Dissertação de Mestrado, Departamento de Antropologia/Universidade de Brasília.

SIGAUD, L. 1979. Os clandestinos e os direitos: estudo sobre trabalhadores da cana-de-açúcar de Pernambuco. São Paulo: Duas Cidades.

STRATHERN, M. (ed.). 2000. Audit cultures: anthropological studies in accountability, ethics, and the academy. London: Routledge.

WEBER, M. 1993. Economía y sociedad. Madrid: Fondo de Cultura Económica. 


\section{Resumo}

No Distrito Federal brasileiro, a distribuição de lotes feita pelo governo local incita milhares de pessoas a se inscreverem em seus programas habitacionais. Para tal, cada sujeito fornece provas documentais que serão classificadas de acordo com as variáveis que figuram em uma equação destinada a estabelecer o quantum de merecimento dos inscritos. Depois de devidamente quantificadas as pessoas são hierarquizadas. Mudanças nos governos implicam modificações nas formas de cálculo. Mudanças na vida das pessoas implicam alterações na sua classificação. Neste artigo, procuro interrogar como essas vicissitudes de uma e outra parte se equilibram a partir de uma crença política a um só tempo comum e instável.

Palavras-chave Teoria Etnográfica, Rituais, Antropologia da Política

\section{Abstract}

In the Brazilian Federal District (Brasilia), the local government's distribution of lots encourages thousands of people to enlist on its housing programs. Applicants are required to provide documentary proofs; these are classified according to variables, which are then fed into an equation designed to calculate the 'quantum' of worthiness of each applicant. After being quantified, each applicant is duly hierarchized. Changes in government mean alterations to the formulas used in this calculation, while changes in people's lives mean alterations to their classification. In this article, I explore how these vicissitudes on both sides balance out on the basis of a political belief which is at once shared and unstable.

Key words Ethnographical Theory, Rituals, Anthropology of Politics 